\title{
THE CORRELATION OF INTERNATIONAL PROSTATE SYMPTOM SCORE (IPSS) WITH QMAX ON UROFLOWMETRY OF BENIGN PROSTATIC HYPERPLASIA (BPH) PATIENTS AT ABDUL WAHAB SJAHRANIE HOSPITAL IN SAMARINDA
}

\author{
Nia Ramadhanurrosita ${ }^{*}$, Boyke Soebhali ${ }^{2}$, Hary Nugroho ${ }^{3}$ \\ ${ }^{1}$ Medical Education Study Program, Medical School of Mulawarman University, Samarinda, \\ Indonesia \\ ${ }^{2}$ Surgery Laboratory, Medical School of Mulawarman University, Samarinda, Indonesia \\ ${ }^{3}$ Anatomy Laboratory, Medical School of Mulawarman University, Samarinda, Indonesia \\ *E-mail: Ramadhanurrositania@gmail.com
}

\begin{abstract}
Background: Benign prostatic hyperplasia (BPH) is one of the most common benign tumors on elderly man. BPH manifests as lower urinary tract symptoms (LUTS). To determine subjectively the symptom severity of LUTS, quantitatively, it was used a diagnostic tool called IPSS. However, IPSS individually is not enough in enforcement of definitive diagnosis man with LUTS. There were some other diagnostics tools used in diagnosing $\mathrm{BPH}$, the other one is uroflowmetry examination that is objective. This research aims are to know the correlation between IPSS and Qmax on uroflowmetry in BPH patients at Abdul Wahab Sjahranie Hospital in Samarinda.

Methods: This research is an analytic survey with observational design, cross sectional. The subject of this research is BPH patients with LUTS at Abdul Wahab Sjahranie Hospital in Samarinda on March until May 2019. Data is collected primarily through the IPSS's questionnaire filled by the patient. Data flow rate obtained through uroflowmetry examination with emphasis on maximum flow rate (Qmax). Results: This research found that BPH is majorly found on group age 60-69 years (45\%). IPSS with moderate symptom severity mostly found on patient $(60 \%)$. Nocturia $(90.5 \%)$ and incomplete emptying $(85 \%)$ is the most frequent symptoms found. The analysis results showed that IPSS had a moderate negative correlation with Qmax on uroflowmetry $(r=-0,567 ; p=0,009)$.

Conclusions: There was correlation between IPSS and Qmax on uroflowmetry of BPH patients at Abdul Wahab Sjahranie Hospital in Samarinda.
\end{abstract}

Keywords: IPSS, uroflowmetry, LUTS, BPH

\section{INTRODUCTION}

Benign prostatic hyperplasia (BPH) is the proliferation of smooth muscle and epithelial cells in the transitional zone of the prostate ${ }^{1}$. McNeal (1976) divides the prostate into five zones namely peripheral zones, central zones, transitional zones, anterior fibromuscular zones, and periurethral zones. Most BPH originates from the prostate transitional zone. ${ }^{2}$

$\mathrm{BPH}$ is one of the most common benign tumors in elderly men ${ }^{3}$. BPH is experienced by $8 \%$ men who are $\geq 40$ years and then increased by $50 \%$ at age $\geq 60$ years and $80 \%$ at age $\geq 90$ years. ${ }^{4}$ Overview of hospital prevalence at Cipto Mangunkusumo Hospital (RSCM) found 3804 cases and the average 
age of sufferers of 66.61 years in 1994-2013 but the exact incidence rate of BPH in Indonesia has never been examined. ${ }^{5}$ The description of BPH cases in Abdul Wahab Sjahranie Hospital in Samarinda according to the research by Gautama (2010) said that there were 1020 medical records with a diagnosis of BPH in the period 1 August 2008 - 31 July 2010.

Patients with BPH suffer prostate enlargement occurs which results in bladder outlet obstruction (BOO) and causes various symptoms of the lower urinary tract (LUTS).$^{7}$ However, the presence of BPH does not always cause LUTS symptoms. In contrast, LUTS symptoms do not always arise due to the presence of $\mathrm{BPH} .^{8}$

Obstruction symptoms due to prostate enlargement and the degree of symptoms on BPH patients can be assessed using a scoring system namely the International Prostate Symptom Score (IPSS) developed by the American Urological Association (AUA) and standardized by the World Health Organization (WHO).$^{5}$ IPSS is a diagnostic tool that is it is subjective but determines the degree of LUTS symptoms quantitatively. ${ }^{3}$ Its use is routinely recommended for men with LUTS when diagnosing and evaluating their treatment. ${ }^{9}$ However, IPSS alone is not sufficient in definitive diagnosis of men with LUTS. ${ }^{9,10}$

There are several diagnostic tools used in diagnosing $\mathrm{BPH}$, including urinalysis, PSA examination, uroflowmetry, PVR and image analysis. ${ }^{3}$ Uroflowmetry is a diagnostic tool for objective urine examination. ${ }^{7}$ One of the information obtained from this examination is the maximum urine emission rate (Qmax) which is related to the presence of BOO. ${ }^{1}$ Uroflowmetry can be used to link symptoms with objective findings ${ }^{9}$.

So on the basis of this knowledge the author wants to examine the correlation between the international prostatic symptom score (IPSS) with Qmax in the uroflowmetry of benign prostatic hyperplasia (BPH) patients in Abdul Wahab Sjahranie Regional Hospital Samarinda.

\section{MATERIAL AND METHOD}

This study uses analytic survey methods to analyze the dynamics of correlation between phenomena with cross sectional observational designs. The research was conducted at the Polyclinic of Abdul Wahab Sjahranie Hospital in Samarinda from March to May 2019.

The population in this study were all patients diagnosed with BPH by urology specialist in the Urology Polyclinic Abdul Wahab Sjahranie Hospital in Samarinda in March-May 2019. Samples in this study were all patients diagnosed with BPH by urology specialists in the Urology Polyclinic at Abdul Wahab Sjahranie Regional Hospital in Samarinda and fulfilled March-May 2019. criteria that have been determined in March-May 2019. Sampling in this study using purposive sampling techniques with the following criteria.

\section{Inclusion Criteria}

1) BPH patients with symptoms of LUTS without complications that have been diagnosed by a urologist.

2) Patients who do uroflowmetry examination with urine volume $>150 \mathrm{ml}$.

3) Patients who re-do uroflowmetry with urine volume $>150 \mathrm{ml}$.

4) Patients who are willing to participate in the study. 


\section{Exclusion Criteria}

1) Patients with LUTS but not diagnosed with BPH.

2) Patients who have received BPH therapy.

The independent variable in this study is the IPSS score collected primarily through the IPSS questionnaire filled out by the patient. The dependent variable is the maximum urine emission rate (Qmax) obtained through uroflowmetry examination. Correlations between variables were analyzed using the Pearson test.

\section{RESULT AND DISCUSSION}

This research was conducted from March to May 2019 at the Urology Polyclinic of Abdul Wahab Sjahranie Hospital in Samarinda with a total sample of 20 people. In this study, the average age of BPH patients was 60.45 years with a minimum age of 48 years and a maximum age of 71 years. The highest number of BPH patients is in the age group of 60-69 years as many as 9 people (45\%) (Table 1). The total IPSS score of 5 is the smallest value and the total score of IPSS 31 is the largest value. IPSS with moderate symptoms (score 8-19) was the most common, occurring in 12 patients (60\%) (Table 2). In this study it was also found that the most common symptom found in BPH patients with LUTS was nocturia (90.5\%) and they felt there was residual after micturition or incomplete emptying (85\%) (Figure 1). This study obtained an average Qmax of $10.38 \mathrm{ml} / \mathrm{s}$ with a minimum Qmax of $7 \mathrm{ml} / \mathrm{s}$ and a maximum Qmax of $15.6 \mathrm{ml} / \mathrm{s}$. BPH patients who experienced obstruction based on Qmax values $<10 \mathrm{ml} / \mathrm{s}$ were found in 7 people $(35 \%)$ (Table 3$)$.

The correlation of IPSS and Qmax on uroflowmetry is known through Pearson test according to the results of normality and homogeneity test (Table 4). Based on the Pearson test results obtained $\mathrm{p}$ value $<0.05$ which indicates that the correlation of IPSS with Qmax on uroflowmetry of BPH patients is significant. Correlation coefficient (r) -0.567 indicates moderate correlation strength and negative correlation (Table 5).

Table 1. The Distribution based on BPH Patient Age at Abdul Wahab Sjahranie Hospital in Samarinda

\begin{tabular}{ccc}
\hline Age & Quantity (people) & Percentage $(\%)$ \\
\hline $\mathbf{4 0 - 4 9}$ & 2 & 10 \\
$\mathbf{5 0 - 5 9}$ & 7 & 35 \\
$\mathbf{6 0 - 6 9}$ & 9 & 45 \\
$\mathbf{7 0 - 7 9}$ & 2 & 10 \\
\hline Total & 20 & 100 \\
\hline
\end{tabular}

Table 2. The Distribution of IPSS scores in BPH patients at Abdul Wahab Sjahranie Hospital in Samarinda

\begin{tabular}{ccc}
\hline IPSS Score & Quantity (people) & Percentage (\%) \\
\hline Mild Symptoms (0-7) & 1 & 5 \\
Moderate Symptoms (8-19) & 12 & 60 \\
Severe Symptoms (20-35) & 7 & 35 \\
\hline Total & 20 & 100 \\
\hline
\end{tabular}


Received : 2019-07-08 Revised : 2019-12-06 Acceptance : 2019-12-12 Publish : 2019-12-31

Table 3. The Distribution of Maximum Urine Beam Velocity in BPH Patients at Abdul Wahab Sjahranie Hospital in Samarinda

\begin{tabular}{|c|c|c|c|c|}
\hline & Mean & 18,30 & \multirow{3}{*}{$\begin{array}{c}\mathbf{p} \\
\text { Value }\end{array}$} & \multirow{4}{*}{$\begin{array}{c}\text { Pearson } \\
\text { Correlation (r) } \\
-0,567\end{array}$} \\
\hline & Range & $5-31$ & & \\
\hline \multirow{2}{*}{$\begin{array}{l}\text { Skor } \\
\text { IPSS } \\
\text { Qmax } \\
(\mathbf{m l} / \mathbf{s})\end{array}$} & Mean & 10,38 & & \\
\hline & Range & $7-15,6$ & 0,009 & \\
\hline
\end{tabular}

Table 4. Normality test and homogeneity test

\begin{tabular}{|c|c|c|}
\hline Statistical Analysis & Variabels & P Value \\
\hline Normality Test (Saphiro- & \multirow{3}{*}{$\begin{array}{c}\text { Skor IPSS } \\
\text { Qmax }\end{array}$} & 0,851 \\
\hline wilk test) & & 0,513 \\
\hline $\begin{array}{l}\text { Homogeneity Test } \\
\text { (Levene test) }\end{array}$ & & 0,925 \\
\hline
\end{tabular}

Table 5. Analysis of IPSS correlation with Qmax on uroflowmetry of BPH patients at Abdul Wahab Sjahranie Hospital in Samarinda

\begin{tabular}{|c|c|c|}
\hline Qmax (ml/s) & Quantity (people) & Percentage (\%) \\
\hline Obstruction $(<10)$ & 7 & 35 \\
Non-Obstruction $(>10)$ & 13 & 65 \\
\hline Total & 20 & 100 \\
\hline
\end{tabular}

Figure 1. The Distribution of Symptoms that Appear in BPH Patients at Abdul Wahab Sjahranie Hospital in Samarinda

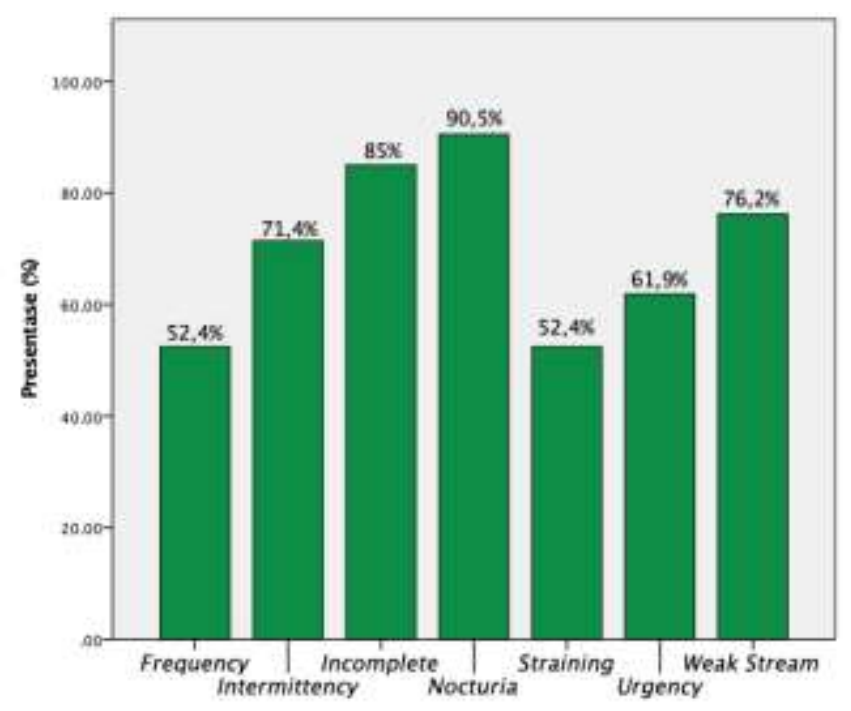

BPH is the most common benign tumor in men and its incidence is related to age ${ }^{3}$. Research on $20 \mathrm{BPH}$ patients at Abdul Wahab Sjahranie Hospital in Samarinda found that the average age of patients was 60.45 years with a range of 48-71 years and most were in the 6069 years age group. This is in line with previous research which showed that the age of most BPH sufferers was found in the age group of 60-69 years with an average age of 64.385 years. The results of other studies showed the same result: the age group 60-69 years is the age group of the most BPH patients with an average age of 67.7 years and 65.2 years, respectively. This study shows an increase in the number of BPH patients with increasing age in accordance with 
the previous statement that $\mathrm{BPH}$ is experienced by $8 \%$ in men who were in the category of age $\geq 40$ years and then increased $50 \%$ at age $\geq 60$ years and $80 \%$ at age $\geq 90$ years. However, the decrease in the number of patients in the 70-79 age group is likely due to the age group having a smaller population than other age groups and many patients in that age group have experienced urinary retention when they visited the hospital so they cannot be sampled in this study.

LUTS is a group of symptoms that are non-specific, non-organ specific, and related to age.${ }^{14}$ Clinically, BPH manifests as LUTS. ${ }^{15}$ In this study, LUTS symptoms that appear in BPH patients are assessed through IPSS scoring. IPSS scoring is used as a guide to direct and determine the presence of obstruction and irritative symptoms that occur during the history of BPH patients. The results showed that IPSS with moderate symptoms was most found in patients $(60 \%)$. Similar results were also obtained in other studies, $58.8 \%$ and $50.2 \%$ of BPH patients in the study had LUTS symptoms with moderate symptoms, respectively. Based on the results of these studies, it can be assumed that most BPH patients came to the hospital when the perceived symptoms has increased to a moderate symptoms.

In addition, this study showed that the most frequent symptoms of LUTS in BPH patients at Abdul Wahab Sjahranie Hospital in Samarinda were nocturia (90.5\%) and they felt there was residual after micturition or incomplete emptying (85\%). This is in line with studies that also found nocturia (71\%) and incomplete emptying (59.9\%) as the most common symptoms of LUTS in BPH patients. Symptoms of nocturia arise in BPH patients due to changes in the structure of the bladder due to overactivity of the detrusor muscle as compensation for obstruction due to prostate enlargement. ${ }^{15}$ Nocturia as the most frequent symptom in BPH patients may be due to several reasons namely the kidneys, bladder, and urethra sphincter that is innervated. by the parasympathetic nerve so that its stimulation will result in vasodilation, renal arteries, contraction of the bladder, and relaxation of the urethral sphincter where at night (especially during sleep) there is a decrease in the effect of sympathetic inhibition of the parasympathetic organs and increased parasympathetic stimulation that causes excitation of the organ which he supplies so that at night urine production will increase, bladder contractions increase, and weakening of the urethral sphincter tone. In addition, decreased antidiuretic hormone $(\mathrm{ADH})$ associated with age and decreased control of the pituitary during sleep and the presence of post-void residuals due to incomplete micturition are also factors that may also increase the frequency of urination at night and cause nocturia to become the most common symptoms .

In this study, there were more Qmax images of uroflowmetry of obese BPH patients (65\%) compared to Qmax obstruction (35\%) so that it was found that most BPH patients in Abdul Wahab Sjahranie Hospital in Samarinda did not experience symptoms of lower urinary obstruction assessed objective of uroflowmetry examination.

Statistical analysis using the Pearson test showed $\mathrm{p}=0.009$ and $\mathrm{r}=-0.567$ which showed that the correlation of IPSS with Qmax in uroflowmetry of BPH patients in Abdul Wahab Sjahranie Hospital was significant with moderate correlation strength and negative correlation. The results of this study are in line with research conducted by Bhomi et al. (2017) on 66 BPH 
patients which got the result that IPSS and Qmax had a strong correlation in the presence of a negative correlation ( $\mathrm{p}<0.01, \mathrm{r}=-0.701$ ). The results of previous studies explained that 50 BPH patients also showed that IPSS with Qmax in uroflowmetry had a significant correlation with strong correlation strength and negative correlation $(\mathrm{p}<0.001, \mathrm{r}=-0.67)$. The results of other studies that show the same thing are studies of $50 \mathrm{BPH}$ patients and studies of $366 \mathrm{BPH}$ patients who also examine all parameters of uroflowmetry with the result that only Qmax is the most important parameter in uroflowmetry clinically. Both of these studies found that IPSS with Qmax on uroflowmetry had a significant correlation with weak correlation strengths and the presence of negative correlations, respectively with $p=0.0075, r=-0.368$ and $p=0.0001$, $r=-0.318$. The results of this study indicate that IPSS and Qmax in uroflowmetry are diagnostic tools that have proven to be meaningful in assessing BPH patients' symptoms at Abdul Wahab Sjahranie Hospital in Samarinda.

\section{CONCLUSION}

Based on the results of the study, it can be concluded that there is a significant correlation with moderate correlation and a negative correlation between IPSS and Qmax on uroflowmetry of BPH patient at Abdul Wahab Hospital Sjahranie in Samarinda.

\section{REFERENCES}

1. American Urological Association. Surgical Management of Lower Urinary Tract Symptoms Attributed to Benign Prostatic Hyperplasia (2018). Retrieved February 13, 2019, from American Urological Association:https://www.auanet.org/guidelines/benignprostatic-hyperplasia/lower-urinary-tract-symptoms (2018).

2. Purnomo, B. B. Hiperplasia Prostat Benigna. In Dasar-dasar Urologi (pp. 125-144). Malang: Sagung Seto (2012).

3. Cooperberg, M. R., Presti Jr, J. C., Shinohara, K., \& Carroll, P. R. Neoplasms of the Prostate Gland. In J. W. McAninch, \& T. F. Lue, Smith \& Tanagho's General Urology (18th Edition ed., pp. 350-357). San Fransisco, California: Mc Graw Hill LANGE (2013).

4. Lim, K. B. Epidemiology of clinical benign prostatic hyperplasia. Asian Journal of Urology, 148-151 (2017).

5. Tjahjodjati, Soebadi, D. M., Umbas, R., Purnomo, B. B., Widjanarko, S., Mochtar, C. A., . . . Hakim, L. Panduan Penatalaksanaan Klinis Pembesaran Prostat Jinak (Benign Prostatic Hyperplasia/BPH) di Indonesia. (pp. 1-31). Jakarta: Ikatan Ahli Urologi Indonesia (IAUI) (2017).

6. Gautama, R. Gambaran Kasus Benign Prostate Hyperplasia (BPH) Berdasarkan Usia, Gejala Penyebab Kunjungan, dan Terapi yang Dijalani di SMF Urologi RSUD Abdul Wahab Sjahranie Samarinda. Universitas Mulawarman, Fakultas Kedokteran, Samarinda (2010).

7. Reynard, J., Brewster, S., \& Biers, S. Pathophysiology and causes of bladder outlet obstruction (BOO) and BPH. In Oxford Handbook of Urology (3rd Edition ed., p. 73). Oxford: Oxford University Press (2013).

8. Roehrborn, C. G. Benign Prostatic Hyperplasia: An Overview. MedReviews, LLC, 7, S4 (2005).

9. Gravas, S., Cornu, J. N., Drake, M., Gacci, M., Gratzke, C., Herrmann, T., . . Tikkine, K. EAU Guidelines on Management of Non-Neurogenic Male Lower Urinary Tract 
Symptoms (LUTS), incl. Benign Prostatic Obstruction (BPO). (pp. 4-63). European Association of Urology (2018).

10. Liao, C.-H., \& Kuo, H.-C. Use of International Prostate Symptom Score voiding-to-storage subscore ratio in assessing lower urinary tract symptoms. Tzu Chi Medical Journal, 61-63 (2014).

11. Jefri, Monoarfa, A., Aschorijanto, A., Monoarfa, R., \& Tubagus, V. Hubungan antara intravesical prostatic protrution, International prostatic symptom score, dan uroflowmetry pada kasus benign prostatic hyperplasia di RSUP Prof. Dr. R. D. Kandou Manado. 9, 121126 (2017).

12. Thapa, N., \& Agrawal, C. Correlation of Uroflowmetry with Lower Urinary Tract Symptoms in Patients with Symptomatic Benign Prostatic Hyperplasia at Eastern Part of Nepal: A Prospective Study. IOSR Journal of Dental and Medical Sciences, 16(1), 86-91 (2017).

13. Patel, N. D., \& Parsons, J. K. Epidemiology and etiology of benign prostatic hyperplasia and bladder outlet obstruction. Indian Journal of Urology, 170-176 (2014).

14. Kaisary, A. F., Ballaro, A., \& Pigott, K. Urology Lecture Notes. In Benign disorders of the prostate gland (7th edition ed., pp. 173-183). West Sussex: John Wiley \& Sons (2016).

15. Eifler, J. B. In J. K. Parsons, J. B. Eifler, \& M. Han, Handbook of Urology (First Edition ed., pp. 157-163). West Sussex: John Wiley \& Sons (2014).

16. Oranusi, C., Nwofor, A., \& Mbonu, O. Correlation between International Prostate Symptom Score and Uroflowmetry in Patients with Benign Prostatic Hyperplasia. Nigerian Journal of Clinical Practice, 20(4), 454-458 (2017).

17. Turk, H., \& Un, S. Correlation between lower urinary tract symptoms and objective measures of uroflowmetry. Archivio Italiano di Urologia e Andrologia, 89(2), 130-133 (2017).

18. Montorsi , F., \& Mercadante, D. Diagnosis of BPH and treatment of LUTS among GPs: a European survey. The International Journal of Clinical Practice, 67(2), 114-119 (2013).

19. Bhomi, K. K., Subedi, N., \& Panta, P. P. Correlation of Visual Prostate Symptom Score with International Prostate Symptom Score and Uroflowmetry Parameters in Nepalese Male Patients with Lower Urinary Tract Symptoms. J Nepal Med Assoc, 56(206), 217-220 (2017).

20. Singla , S., Garg, R., Singla, A., Sharma, S., Singh, J., \& Sethi, P. Experience with Uroflowmetry in Evaluation of Lower Urinary Tract Symptoms in Patients with Benign Prostatic Hyperplasia. 8(4), 1 (2014).

21. Porru, D., Bartoletti, R., Austoni, E., Carrino, M., Gianneo, E., \& Melloni, D. Relationship of Flow Rate with Symptoms, Quality of Life, and Other Clinical Parameters in Patients with LUTS Suggestive of BPH. Eropean Urology, 40(1), 23-27 (2001). 